\title{
Large scale transfection of mouse L-cells by electropermeabilization
}

\author{
H. Stopper, H. Jones and U. Zimmermann \\ Lehrstuhl für Biotechnologie, Universität Würzburg, Röntgenring 11, Würzburg (F.R.G.)
}

(Received 27 November 1986)

Key words: Electrical breakdown; Electropermeabilization; Volume distribution; Gene transfer; Transfection; (Mouse L-cell)

Mouse L-cells were transfected by electropermeabilization using the selectable plasmid pSV2-neo which confers resistance to $\mathrm{G}-418$ (Geneticin). The DNA concentration used was $1 \mu \mathrm{g} / \mathrm{ml}$, the field strength was $10 \mathrm{kV} / \mathrm{cm}$, the duration of the pulse was $5 \mu \mathrm{s}$. Transfection yield was optimal at a temperature of $4^{\circ} \mathrm{C}$ when using a time in between consecutive pulses of 1 minute compared to shorter (of the order of seconds) or longer (3 minutes) time intervals. A more detailed study of the relationship between the number of pulses applied (up to 10) and transfection yield showed it to be almost linear in this range at $4^{\circ} \mathrm{C}$. The yield of transfectants in response to 10 pulses was up to 1000 per $10^{6}$ cells (using $3.3 \mathrm{pg}$ DNA per cell). The influence of the growth phase of the cells on the transfection yield and/or the subpopulation of the mouse L-cell line used was shown. Furthermore the clone yield depended on the DNA per cell ratio within a very small range.

\section{Introduction}

The electropermeabilization (electrical breakdown of cell membranes) technique [1-9] is becoming increasingly popular for gene transfer in a variety of eukaryotic cell types. Recently the technique has been successfully applied in the transfection of yeast spheroplasts $[6,10]$, plant protoplasts [11,12], and mammalian cells [7,9,13-15]. The appeal of the technique lies in its relative simplicity compared to conventional techniques, its greater degree of control and reproducibility, and the avoidance of chemical reagents such as poly(ethylene glycol) which are often lethal to cells. Moreover, transfection frequency is comparable and usually superior to the conventional chemical techniques.

Although transfection is often achieved by the

Correspondence: U. Zimmermann, Lehrstuhl für Biotechnologie, Universität Würzburg, Röntgenring 11, D-8700, Würzburg, F.R.G. application of more than one pulse $[10,11,13,15]$, there seems to have been no detailed study into the effect of the number of pulses, the effect of temperature, and of the time interval between the pulses on transfection yield. It is expected that yield should increase with an increase in the num. ber of applied pulses until a situation is reached in which there is a balance between reduced cell viability, caused by excessive leakage from the cell interior, and DNA uptake. On the other hand the time interval between the pulses, and temperature in particular, may be important for membrane resealing and thus on the ability of the cell to build up a breakdown potential between the pulses. In the past sequences of electrical pulses have been applied in transfection experiments with a time interval between the pulses of only a few seconds and usually, but not always [15], at unfavourable temperatures (see, for example, Refs. $10,13,14)$.

In the present communication we report further improvements in the yield of transfection of mouse 
L-cells by circumventing some of the shortcomings of previous experiments. This has been achieved by a detailed study into the effect of temperature, number of pulses, and time interval between the pulses on transfection yield. Furthermore, some of the variations in the yield of transfection obtained in previous experiments [9-15] are reconciled by studies which indicate that the size distribution (as determined using a hydrodynamically focusing particle analyzer [16]) of the cell population to be transfected is of importance in relation to transfection yield. These experiments also show that considerable variation may also arise from transfecting different subpopulations of the same cell line (established by independent culturing). In this way extremely good yields of up to 1000 transfectants per $10^{6}$ cells and per 1 $\mu \mathrm{g} / \mathrm{ml}$ DNA were obtained.

\section{Materials and Methods}

Cell culture. Mouse L-cells were grown in RPMI 1640 medium supplemented with $5 \%$ fetal calf serum (FCS), glutamine, non-essential amino acids, and streptomycin/penicillin antibiotics. Three subpopulations were cultured, and numbered $\mathrm{H}-1$ to $\mathrm{H}-3$ (for explanation see Results).

$D N A$. Plasmid DNA, pSV2-neo [17], confering resistance to G-418 was isolated from Escherichia coli. After linearizing the plasmid with EcoRl the degree of purity and linearity was further confirmed by agarose gel electrophoresis.

Enzymic pretreatment. The culture medium used for growing the cells was decanted and replaced by a culture medium containing $0.1 \mathrm{mg} / \mathrm{ml}$ dispase $(6 \mathrm{U} / \mathrm{mg}$, grade 1 , Boehringer, Mannheim). This was necessary in order to detach the cells from the surface of the culture vessel, and to remove or at least modify the structure of the glycocalyx external to the plasmalemma for DNA uptake to occur.

Electric field application. After washing the cells with culture medium and pulse medium $(30 \mathrm{mM}$ $\mathrm{KCl}, 220 \mathrm{mM}$ inositol, and $1 \mathrm{mM}$ phosphate buffer (pH 7.2)), the cells were for field application suspended in pulse medium as described previously [15]. Field application was achieved using a capacitor discharge method as described in previous publications [2-8]. The discharge chamber consisted of two flat, parallel platinum electrodes mounted in a rectangular well in a plexiglass block. The chamber volume was either $2.5 \mathrm{ml}$ or $1.2 \mathrm{ml}$. The number of cells used was $0.75 \cdot 10^{6}$ in the $2.5 \mathrm{ml}$ chamber and $1.2 \cdot 10^{6}$ in the $1.2 \mathrm{ml}$ chamber. The DNA concentration added before field application was $1 \mu \mathrm{g} / \mathrm{ml}$ in both cases. We therefore calculated the cell per DNA ratio to be $3.3 \mathrm{pg} /$ cell in the larger volume of $2.5 \mathrm{ml}$ and 1.0 $\mathrm{pg} /$ cell in the smaller volume of $1.2 \mathrm{ml}$. The field strength used was $10 \mathrm{kV} / \mathrm{cm}$ and the pulse duration was $5 \mu \mathrm{s}$ [15].

Membrane resealing. After pulsing, the cell suspension was transferred to a resealing medium $(120 \mathrm{mM} \mathrm{NaCl}, 10 \mathrm{mM} \mathrm{KCl}, 0.5 \mathrm{mM}$ magnesium acetate, $0.1 \mathrm{mM}$ calcium acetate, and $10 \mathrm{mM}$ phosphate buffer ( $\mathrm{pH} \mathrm{7.2))} \mathrm{at} 37^{\circ} \mathrm{C}$ as described previously $[2,3,15]$. The cells were left to reseal in this medium for $20 \mathrm{~min}$ at $37^{\circ} \mathrm{C}$ and were then centrifuged and transferred to $1 \mathrm{ml}$ of culture medium with the fetal calf serum level raised to $10 \%$. Cell counting and viability check (assessed by trypan blue staining) were now performed using the Neubauer chamber. The cell suspension was then further diluted with culture medium $(10 \%$ FCS) and then transferred into cell culture vessels and incubated.

Post-transfection culturing and selection of clones. After $48 \mathrm{~h}$ incubation the culture medium was removed and replaced by culture medium (5\% fetal calf serum) containing $500 \mu \mathrm{g} / \mathrm{ml} \mathrm{G}-418$ (Gibco). Dead cells were removed by changing the selection medium on several occasions up to the 12th day after transfection. Stable transfectants were enumerated by counting colonies between the 10th and 12th day. The results are expressed as colonies per $10^{6}$ cells and per $1 \mu \mathrm{g} / \mathrm{ml}$ DNA counted after the resealing period.

Measurements of cell size distribution. The size distributions of different cell populations were determined using a hydrodynamically focusing particle analyzer (measured in culture medium at a rate of 1000 counts per second with a cylindrical orifice of $60 \mu \mathrm{m}$ in length and diameter, orifice current $0.3 \mathrm{~mA}$, pressure difference $0.02 \mathrm{MPa}$, and gain 5). The theory and practice behind this technique has been reported elsewhere (see, for example, Refs. 3, 4, 16). Where indicated measurements were made exactly in parallel with the transfection experiments. 


\section{Results}

In the following experiments we used exponentially growing cell populations of the subpopulation $\mathrm{H}-3$ and a DNA concentration of $3.3 \mathrm{pg}$ per cell unless otherwise stated. A comparison of the effect on yield of applying a single and a train of five electrical pulses $1 \mathrm{~min}$ apart at temperatures of either 4 or $37^{\circ} \mathrm{C}$ is shown in Table I. It is evident that the yield is much better when a train of electrical pulses is applied compared to singlepulse application both at 4 and $37^{\circ} \mathrm{C}$. The number of transfectants was increased in response to 5 pulses from about 35 to 350 clones per $10^{6}$ cells and per $1 \mu \mathrm{g} / \mathrm{ml}$ DNA at $4^{\circ} \mathrm{C}$. At $37^{\circ} \mathrm{C}$ the effect was less pronounced with the number of transfectants only increasing from around 40 to 270 clones per $10^{6}$ cells. The corresponding effect on cell viability (as assessed by trypan blue staining) is also shown in Table I. Compared to a single pulse at $4^{\circ} \mathrm{C}$, a train of five electrical pulses showed no effect on the viability. On the other hand, at a temperature of $37^{\circ} \mathrm{C}$ the viability was much more reduced in response to a train of five pulses as compared to a single pulse. The viability in response to a single pulse was the same at both 4 and $37^{\circ} \mathrm{C}$. This experiment was repeated on another occasion at temperatures of 4 and $23^{\circ} \mathrm{C}$. A similar trend was obtained to that shown in Table I. From the results presented it seems preferable to perform transfection experiments at around $4{ }^{\circ} \mathrm{C}$ compared to higher temperatures. All subsequent experiments were therefore carried out at a temperature of $4^{\circ} \mathrm{C}$.

\section{TABLE I}

Effect on the transfection yield of applying a single pulse and a train of five electrical pulses $1 \mathrm{~min}$ apart at a temperature of $4^{\circ} \mathrm{C}$ and $37^{\circ} \mathrm{C}$. The corresponding effect of the treatments on cell viability is also shown. The experiment was carried out using a DNA per cell ratio of $3.3 \mathrm{pg} /$ cell and cell subpopulation H-3 (see Table V). The results are presented as means \pm S.D.

\begin{tabular}{llllll}
\hline Temp. & $4^{\circ} \mathrm{C}$ & & $37^{\circ} \mathrm{C}$ & \\
\cline { 2 - 3 } \cline { 5 - 6 } No. of pulses & 1 & 5 & 1 & \multicolumn{1}{l}{5} \\
\hline Clones $/ 10^{6}$ cells & $37 \pm 12$ & $349 \pm 13$ & $40 \pm 8$ & $272 \pm 37$ \\
Viability (\%) & 53 & $51 \pm 3$ & $55 \pm 2$ & $23 \pm 2$ \\
\hline
\end{tabular}

\section{TABLE II}

The effect on transfection yield of the time interval between the electrical pulses at $4^{\circ} \mathrm{C}$. A DNA per cell ratio of 3.3 $\mathrm{pg} /$ cell with three applied pulses was used. The control cells were not subjected to electrical pulses and the concentration of DNA used was also $3.3 \mathrm{pg}$ per cell. The cell subpopulation used was H-3. The results are presented as means \pm S.D.

\begin{tabular}{lllll}
\hline & Control & \multicolumn{3}{l}{ Time interval } \\
\cline { 2 - 5 } & & $5 \mathrm{~s}$ & $60 \mathrm{~s}$ & $180 \mathrm{~s}$ \\
\hline Clones $/ 10^{6}$ cells & $8 \pm 7$ & $80 \pm 40$ & $122 \pm 34$ & $106 \pm 2$ \\
\hline
\end{tabular}

The effect of the time interval between the pulses was investigated and the results are shown in Table II. Transfection yield was best when the time interval between the pulses was $1 \mathrm{~min}$ (around 120 clones) compared to shorter (of the order of seconds, around 80 clones) or longer $(3$ minutes, around 105 clones) time intervals.

Having established that a temperature of $4^{\circ} \mathrm{C}$ and a time interval between the pulses of $1 \mathrm{~min}$ are near optimal for transfection, the relationship between the number of electrical pulses and transfection yield was investigated in greater detail. Fig. 1 shows the effect of applying up to 10 electrical pulses $1 \mathrm{~min}$ apart at a temperature of

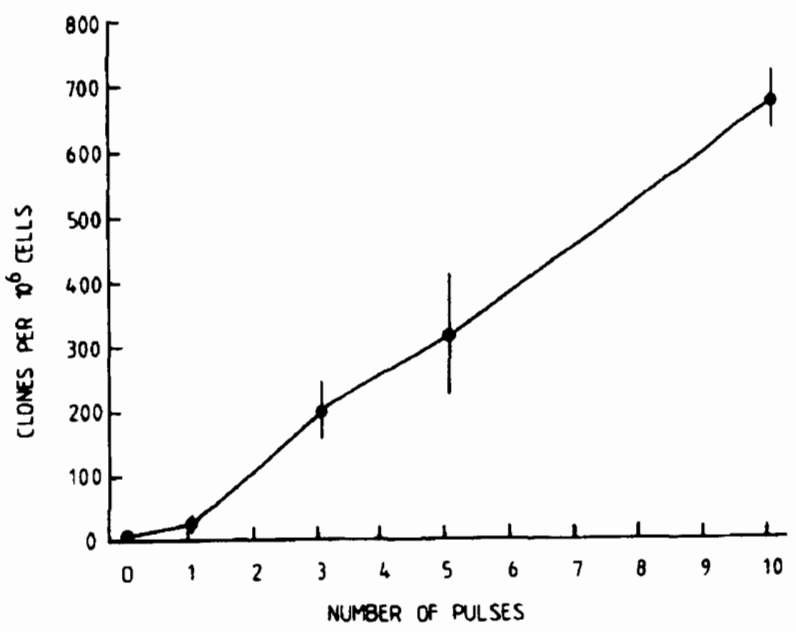

Fig. 1. The relationship between transfection yield and the number of applied pulses at $4^{\circ} \mathrm{C}$. The time interval between the pulses was $1 \mathrm{~min}$. (The corresponding effect on cell viability is shown in Table III). A DNA per cell ratio of $3.3 \mathrm{pg} /$ cell and subpopulation H-3 were used in this experiment. The results are presentod as mean \pm S.D. 
TABLE III

The relationship between the number of applied pulses at $4^{\circ} \mathrm{C}$ and cell viability. For transfection yield see Fig. 1.

\begin{tabular}{llllll}
\hline \multicolumn{5}{c}{ Number of pulses } & \\
\cline { 2 - 6 } & 0 & 1 & 3 & 5 & 10 \\
\hline Viability (\%) & $66 \pm 2$ & $72 \pm 4$ & $72 \pm 1$ & $68 \pm 7$ & $51 \pm 5$ \\
\hline
\end{tabular}

TABLE IV

When 'exponential cells' and 'dense cells' (see Fig. 2 for explanation), both belonging to subpopulation $\mathrm{H}-3$, were transfected by the application of 3 electrical pulses $1 \mathrm{~min}$ apart with a DNA per cell ratio of $3.3 \mathrm{pg} / \mathrm{cell}$ at a temperature of $4^{\circ} \mathrm{C}$, the results shown here were obtained. With the controls no electrical pulses were applied and the DNA concentration used was the same as in the treatments. The results are presented as means \pm S.D.

\begin{tabular}{llll}
\hline & Control & $\begin{array}{l}\text { Exponential } \\
\text { cells }\end{array}$ & $\begin{array}{l}\text { Dense } \\
\text { cells }\end{array}$ \\
\hline Clones $/ 10^{6}$ cells & $8 \pm 8$ & $262 \pm 3$ & $102 \pm 15$ \\
\hline
\end{tabular}

$4^{\circ} \mathrm{C}$ on clone yield. It is clear that clone yield is almost a linear function of the number of applied pulses. It should be noted that in the absence of electrical pulsing (but in the presence of DNA) the transfectants obtained were only few in number. After applying 10 pulses the yield of transfectants obtained was around 680 clones per $10^{6}$ cells. It should be mentioned at this point that in response to three electrical pulses clone yield was similar to that obtained in Table II and clone yield obtained with five pulses was within the range of that in Table I, each under comparable conditions and taking account of the standard deviations. An examination of Table III shows that cell viability is significantly reduced from around $70 \%$ to $50 \%$ in response to 10 pulses. This indicated that the balance between cell viability and DNA uptake may be approaching optimal when 10 electrical pulses are applied in this way. Microscopic examination of the cells immediately after resealing showed that the viable cells almost doubled in diameter in response to 10 pulses without being stained by trypan blue. This indicates that despite an increase in cell volume the cell membrane remained intact.

Variations in the data presented in this paper and in our previous publication [15] are reconciled by studies which indicate that the cell growth density and/or different cell subpopulations of the same cell line (see below) to be transfected are important in relation to clone yield. Fig. 2 shows the size distribution of two cell populations (of the same subpopulation) one of which was in an early exponential growth phase and the other of which was at this point in a dense post-exponential growth phase. It should be mentioned that all the other experiments were performed using exponentially growing cells in between these two extremes. It is clearly shown that the early exponential phase

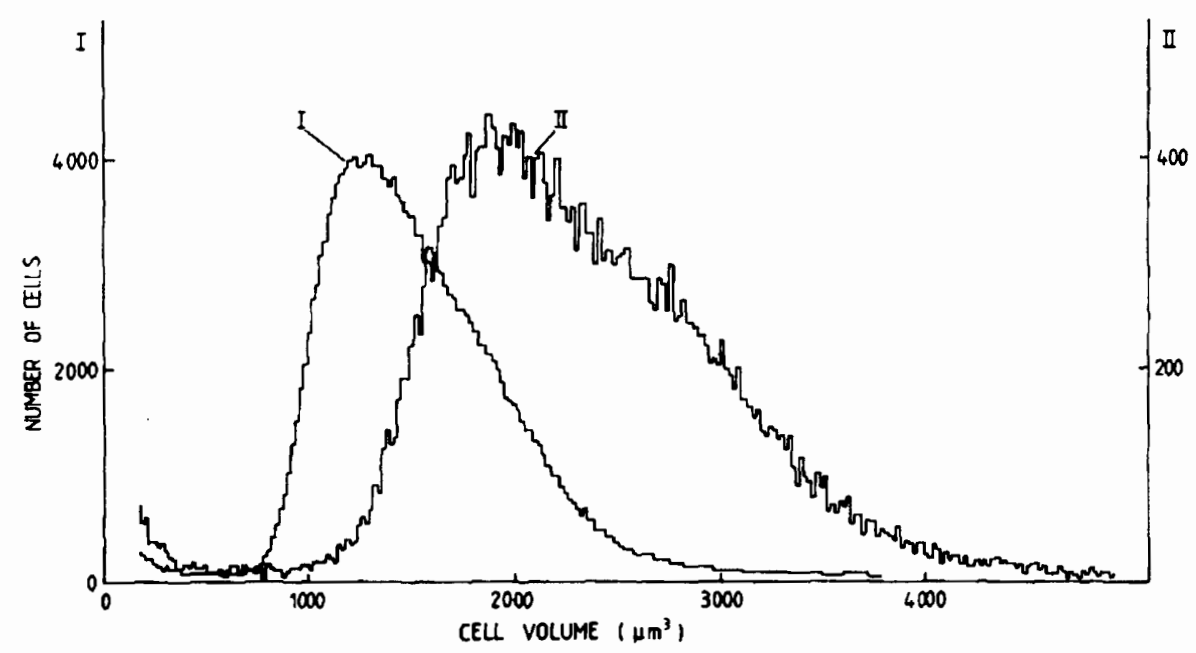

Fig. 2. The size distribution of a dense post-exponential cell population ('dense cells', ' $I$ ') and an early exponentially growing cell population ('exponential cells', 'II'). (For transfection results with these two different cell populations see Table IV.) 
cells (modal volume of $1956 \mu \mathrm{m}^{3}$ ) had significantly larger volumes than the dense post-exponential phase cells (modal volume of $1252 \mu \mathrm{m}^{3}$ ). When these two different cell populations were transfected the results presented in Table IV were obtained. Transfection yield in the larger volumed early exponential phase cells was more than double that of the smaller volumed post-exponential phase cell. A yield of around 260 clones per $10^{6}$ cells was obtained when transfecting the early exponential phase cells and around 100 clones per $10^{6}$ cells with the post exponential phase cells. The clone yield obtained in Table II and Fig. 1 from transfecting exponentially growing cells with 3 pulses are within these extremes of values. The post-exponential phase cells were obtained by growing cells from an initial inoculum of around $1 \cdot 10^{6}$ cells for 4 days without change of medium.

From the results presented in Fig. 2 and Table IV it is apparent that the modal cell volume of the cell population to be transfected is of importance in relation to transfection yield. However, this is not the only determinant since experiments also established that considerable yield variation may arise when transfecting different subpopulations of the same cell line where there was no apparent correlation between the modal cell volume (ranging from 1660 to $2130 \mu \mathrm{m}^{3}$ ) of the different subpopulations and clone yield. Such an experiment is shown in Table V, in which it should be noted that the DNA per cell ratio was also lowered (to $1.0 \mathrm{pg} /$ cell). It is clear from these results that considerable variation in yield may exist from one subpopulation to the next. The trend in yield obtained in response to five pulses was the same as that obtained with 10 pulses, with the clone yield of course higher in the latter case. The experiment also showed that decreasing the DNA per cell ratio lead to much smaller clone yields than in experiments under otherwise comparable conditions (see Fig. 1). Using the most efficient subpopulation $\mathrm{H}-1$, which was only available during these last experiments, yielded $990 \pm 162$ clones (Table V) per $10^{6}$ cells under optimum conditions with a DNA per cell ratio of $3.3 \mathrm{pg} /$ cell. The result with subpopulation $\mathrm{H}-3$ under these conditions (not shown) was within the standard deviation of that in Fig. 1 under identical conditions.

\section{Discussion}

The clone yields reported here of up to 1000 clones per $10^{6}$ cells are much higher than those previously obtained for the mouse L-cell system [15] or any other system [7,8,10-14]. The results show that, even with very low DNA concentrations, provided appropriate conditions are used, the combined heat shock/PEG/carrier DNA system recently reported by Shillito et al. [11] for the transfection of protoplasts is not required. In this latter study the highest clone yield obtained was around 900 colonies $/ 10^{6}$ protoplasts per $10-100$ $\mu \mathrm{g}$ DNA. It can be argued that plant protoplasts are more difficult to electropermeabilize than mammalian cells. However, the bulk of the literature published so far suggests the opposite to be true (see review articles, Refs. 2-8).

Several physical and biological parameters have to be carefully considered when using the electropermeabilization technique for transfection. Our observations concerning the effect of temperature confirm our long standing belief $[1-8,15]$ that the incorporation of foreign molecules at low temperature is preferable to that at higher temperatures

\section{TABLE V}

The effect on yield of transfecting different subpopulations (H-1, H-2, H-3) of mouse L-cells with a DNA per cell ratio of $1.0 \mathrm{pg} / \mathrm{cell}$ and in one case (where indicated) $3.3 \mathrm{pg} / \mathrm{cell}$. The time interval between the pulses was $1 \mathrm{~min}$ and the temperature was $4^{\circ} \mathrm{C}$. The control cells were not pulsed and the DNA concentration was the same as that used for treated cells. The results are presented as means \pm S.D.

\begin{tabular}{|c|c|c|c|c|c|c|c|c|}
\hline \multirow[t]{3}{*}{ Subpopulation } & \multirow[t]{3}{*}{ Control } & \multicolumn{7}{|c|}{ Number of pulses } \\
\hline & & \multicolumn{3}{|l|}{5} & \multicolumn{3}{|l|}{10} & \multirow{2}{*}{$\frac{10(3.3 \mathrm{pg} / \text { cell }}{\mathrm{H}-1}$} \\
\hline & & $\overline{\mathrm{H}-1}$ & $\mathrm{H}-2$ & H-3 & $\overline{\mathrm{H}-1}$ & H-2 & H3 & \\
\hline Clones $/ 10^{6}$ cells & $10 \pm 4$ & $195 \pm 28$ & $101 \pm 41$ & $134 \pm 48$ & 429 & $232 \pm 25$ & $372 \pm 67$ & $990 \pm 162$ \\
\hline
\end{tabular}


$[10,13]$. Transfection yield and viability of the cells were much better at $4^{\circ} \mathrm{C}$ as compared to $23^{\circ} \mathrm{C}$ (results not shown) or $37^{\circ} \mathrm{C}$ (Table I). Experiments below $4^{\circ} \mathrm{C}$ (as carried out by Potter et al. [14]) were not performed because of the irreversible deterioration of the membrane at this temperature under electric field conditions [18]. Work on lipid bilayer membranes [19] and on the giant algal cells of Valonia utricularis [18] have shown that the breakdown voltage of a membrane unit at $37^{\circ} \mathrm{C}$ is about $0.5 \mathrm{~V}$, at $20^{\circ} \mathrm{C}$ about $1 \mathrm{~V}$, and at $4^{\circ} \mathrm{C}$ about $2 \mathrm{~V}$ (if appropriate pulse lengths are used [4]). From these results it can easily be calculated $[4,5,8]$ that $10 \mathrm{kV} / \mathrm{cm}$, as used in our experiments, induces a reversible electrical breakdown at $4^{\circ} \mathrm{C}$ in most of the cells whereas at $23^{\circ} \mathrm{C}$ or $37^{\circ} \mathrm{C}$ it possibly induces an irreversible electrical breakdown for a larger percentage of the cells because of the temperature dependence discussed above. It can be argued that viability may be improved at $23^{\circ} \mathrm{C}$ and $37^{\circ} \mathrm{C}$ by lowering the field strength. However, as shown previously $[2,3,8]$ and presently, the duration of the field-induced permeabilized state of cell membranes at 23 and $37^{\circ} \mathrm{C}$ is much less than at $4^{\circ} \mathrm{C}$ and may therefore reduce the chance of uptake of macromolecules [20].

Experiments established that transfection was much better when the time interval between the pulses was 1 minute compared to shorter (of the order of seconds) or longer ( 3 minutes) time intervals (Table II). This observation can be explained theoretically by the membrane potential distribution of cells in electric fields [2-8]. In response to a single pulse the potential build up across the untreated membrane is greatest at membrane sites oriented in the field direction and progressively decreases towards zero at sites located perpendicular to the field direction. These locations perpendicular to the field direction can never be electropermeabilized. The situation is further complicated by studies which show that asymmetric permeabilization of the two hemispheres oriented in the field direction can occur [7,21]. Thermalconvectional, diffusional, and rotational events between the pulses with a $1 \mathrm{~min}$ interval should therefore be expected to expose these relatively unpermeabilized areas of the membrane to the electrical field in response to successive pulsing.
Yield enhancement in this way therefore probably reflects a greater degree of membrane permeabilization which thus improves the chance of DNA uptake occurring. Another important aspect is that a time interval of 1 minute between the pulses seems to be of sufficient duration at $4^{\circ} \mathrm{C}$ for membrane resealing to occur to such an extent that a breakdown potential can be built up across the cell membranes. When the time interval between the pulses is of the order of seconds the resealing process at $4^{\circ} \mathrm{C}$ is incomplete $[20,22]$ with the 'pores' remaining open thus leading to a short circuit through the cell interior instead of building up a breakdown potential across the membrane [23] which, as shown previously [2,3], leads to cell death. This explains why in our previous study [15] the application of a train of three pulses did not lead to yield improvement. This also explains why Karube et al. [10] found that a train of electrical pulses led to a reduction in cell viability and the corresponding clone yield. It is clear, for this reason and also because of the long pulse duration of $50 \mu \mathrm{s}$ used by these authors, that the current lines were going through the cell interior. Therefore a train of 10 pulses only leads to a high yield if the appropriate time interval is chosen as shown in Fig. 1. The observation that the diameter of the cells almost doubled after resealing in response to the application of 10 electrical pulses may also be significant. The flow of water into the cell may be coupled with a DNA flow that caused the yield increase. This increase in volume can be explained by the colloid osmotic pressure theory [22].

Not only do biophysical parameters have to be taken into account but also the biological parameters have to be considered. Electrical pulsing of early exponentially growing cells as compared to dense post-exponential cells resulted in more than a doubling of transfection yield (Table IV). This was found to correlate with the size distribution of the different cell populations (Fig. 2) where it was shown that the early exponentially growing cells had a significantly larger modal volume than those of the dense post-exponential phase cells. More detailed studies in the future using cell synchronization techniques combined with cell sizing and the transfection of cells at specific stages of the cell cycle should throw light on whether the size of 
the cells and/or cell cycle events are important in this respect.

However, when designing such experiments we have to be aware of the subpopulation problem discussed. As shown here the yield of stably transfected L-cells is dependent on the subpopulation used although the biophysical and growth conditions were held constant. The variations between the subpopulations may be due to either different membrane permeability and/or DNA uptake, integration, and expression.

The characterization of subpopulations is important in the future for establishing high yielding cell lines. At the same time more work has to be carried out to establish the relationship between the DNA per cell ratio and the different subpopulations if further improvement in yields are to be realized. The data reported here show that very small changes in the DNA per cell ratio of only 3.3 can greatly effect at a given subpopulation the yield of transfection.

\section{Acknowledgements}

We would like to thank Dipl.-Phys. H.G. Broda, P. Kleinhans, and U. Höfling for the measurements of the volume distributions. We also want to thank Dr. G. Neil, Department of Immunology, Resarch Institute of Scripps Clinic, La Jolla, CA, U.S.A., for critical discussion of the manuscript. This work was supported by grants of the DFG (SFB 165 and 176) to U. Zimmermann.

\section{References}

1 Zimmermann, U., Riemann, F. and Pilwat, G. (1978) U.S. Patent No. 4081340

2 Zimmermann, U., Pilwat, G., Beckers, F. and Riemann, F. (1976) Bioelectrochem. Bioenerg. 3, 58-83
3 Zimmermann, U., Vienken, J. and Pilwat, G. (1980) Bioelectrochem. Bioenerg. 7, 553-574

4 Zimmermann, U., Scheurich, G., Pilwat, G. and Benz, R. (1981) Angew. Chemie, Int. Edn. Eng. 20, 325-344

5 Zimmermann, U. (1982) Biochim. Biophys. Acta 694, 227-277

6 Zimmermann, U., Vienken, J., Halfmann, J. and Emeis, CC. (1985) in Advances in Biotechnological Processes, Vol. 4 (Mizraki, A. and Van Wezel, A.Z., eds.), pp. 79-150, Alan, R. Liss, New York

7 Zimmermann, U. and Stopper, H. (1986) Pharma Technol. J. 26-36

8 Zimmermann, U. (1986) Rev. Physiol. Biochem. Pharmacol. 105, 175-256

9 Auer, D., Brandner, G. and Bodemer, W. (1976) Naturwissenschaften 63, 391

10 Karube, I., Tamiya, E. and Matsuoka, H. (1984) FEBS Lett. 182, 90-94

11 Shillito, R.D., Saul, M.W., Paszkowski, J., Muller, M. and Potrykus, 1. (1985) Biotechnology 3, 109 113

12 Fromm, M.E., Taylor, L.P. and Walbot, V. (1986) Nature $319,791-793$

13 Neumann, E., Schaefer-Ritter, M., Wang, Y, and Hofschneider, P.H. (1982) EMBO J. 1, 841-845

14 Potter, H., Weir, L. and Leder, P. (1984) Proc. Natl. Acad. Sci. USA 81, 7161-7165

15 Stopper, H., Zimmermann, U. and Wecker, E. (1985) Z. Naturforsch. 40c, 929-932

16 Broda, H.G., Schnettler, R. and Zimmermann, U. (1987) Biochim. Biophys. Acta 899, 25-34

17 Southern, P.J. and Berg, P. (1982) J. Med. Appl. Genet. 1, 327-341

18 Coster, H.G.L. and Zimmermann, U. (1975) J. Membrane Biol. 22, 73-90

19 Benz, R., Beckers, F. and Zimmermann, U. (1979) J. Membrane Biol. 48, 181-204

20 Zimmermann, U., Riemann, F. and Pilwat, G. (1976) Biochim. Biophys. Acta 436, 460-474

21 Mehrle, W., Zimmermann, U. and Hampp, R. (1985) FEBS Lett. 185, 89-94

22 Zimmermann, U., Pilwat, G., Holzapfel, C. and Rosenheck, K. (1976) J. Membrane Biol. 30, 135-152

23 Pethig, R. (1979) Dielectric and Electronic Properties of Biological Materials, John Wiley and Sons, Chichester, New York, Brisbane, Toronto 